\title{
ORAL HEALTH KNOWLEDGE AND ATTITUDE, ORAL HEALTH STATUS IN ELDERS AND ITS IMPACT ON GENERAL WELL-BEING
}

\author{
(PENGETAHUAN DAN PERILAKU TENTANG KESEHATAN RONGGA MULUT, \\ STATUS KESEHATAN MULUT PADA LANSIA DAN IMPLIKASINYA \\ PADA KESEHATAN UMUM)
}

\author{
Munifah Abdat*, Tanti Jernita \\ Faculty of Dentistry, Universitas Syiah Kuala, Banda Aceh, Indonesia \\ *Corresponding e-mail: nafa_doc@yahoo.com
}

\begin{abstract}
Elderly is the last phase in human life and unavoidable. Elderly experienced the natural process which changes in body tissue function include changes in oral tissues such as dry mouth, pale mucosa, mucosal thinning, attrition, and tooth loss. Maintaining the health of oral cavity is one of way to maintain body condition for the elders. This study aims to determine the knowledge and behavior of oral health and its status in the elders and its implications for general well-being. This study was an analytical study with a cross sectional approach, taking research subjects by purposive sampling and obtained 40 elderly people. The results showed that oral health status was poor in average according to the stipulated criteria (DMF-T=11,725; OHIS $>3.1=57.5 \%$ ) and the elders complained of impaired speech function, chewing and swallowing food. There was a significant relationship between knowledge and oral health behavior with DMFT $(r=0.835)$ and OHIS $(r=0.828)$. It was concluded that poor oral health status in the elders could have implications for health problems both locally in the oral cavity and the body in general.
\end{abstract}

Keywords: oral health status, elderly, health implications

\begin{abstract}
Abstrak
Lanjut usia atau lansia merupakan fase akhir dari siklus kehidupan manusia yang tidak dapat dihindari. Lansia mengalami proses alamiah dimana terjadi perubahan fungsi jaringan tubuh termasuk perubahan jaringan mulut seperti mulut kering, mukosa pucat, penipisan mukosa, atrisi dan kehilangan gigi. Menjaga kesehatan rongga mulut merupakan salah satu cara menjaga kondisi tubuh bagi lansia. Penelitian ini bertujuan untuk mengetahui pengetahuan dan perilaku tentang kesehatan ronggamulutdan status kesehatan mulut pada lansia serta implikasinya pada kesehatan secara umum. Penelitian ini adalah penelitian analitik cross sectional, pengambilan subyek penelitian secara purposive sampling dandiperoleh 40 orang lansia. Hasil penelitian menunjukkan status kesehatan rongga mulut lansia rata-rata memiliki criteria buruk (DMF-T=11,725; OHIS $>3,1=57,5 \%$ ) dan lansia mengeluhkan adanya gangguan fungsi berbicara, mengunyah serta menelan makanan. Terdapat hubungan yang signifikan antara pengetahuan dan perilaku kesehatan rongga mulut dengan DMFT $(r=0,835)$ dan OHIS $(r=0,828)$. Disimpulkan bahwa status kesehatan mulut yang buruk pada lansia dapat berimplikasi terhadap gangguan kesehatan baik lokal di rongga mulut maupun tubuh secara umum.
\end{abstract}

Kata kunci: status kesehatan mulut, lansia, implikasi kesehatan

\section{INTRODUCTION}

The national social economic urvery (Susenas) 2014 stated that the population of elderly citizens in Indonesia is reaching 20.24 million, equivalent to $8.03 \%$ of Indonesian total citizen. ${ }^{1}$ The increasing number of elders is in accordance with the life ex- pectancy of Indonesian citizens. ${ }^{2}$ There are four classifications of elders, according to World Health Organization (WHO): middle age at 45-59 years old, elders at 60-74 years old, old at 75-90 years old and very old at 90 years old above. ${ }^{3}$ Following 
is the classification of elderly according to the Department of Health (2003): pre-elderly at 45-59 years old, elderly at 60 years old and above, high risk elderly at 70 years old and above, potential elderly and non-potential elderly. ${ }^{4}$

Aging is a natural process where changes occur to body tissues and complex body organs, including changes in oral tissues. ${ }^{5}$ Changes in oral cavity for elderly include dry mouth, pale mucosa, mucosal thinning, attrition, and tooth loss. The impaired mastication oftenly occurs on individuals with less than 20 or 10 pairs of teeth with good oclusion. ${ }^{6,7}$

Oral and dental health is fundamental to health in general. The poor oral health will cause tooth loss and individual systemic health, tooth loss by the untreated hole or trauma will disturb the function and activities in oral cavity, which will impact the nutrient status and eventually the quality of life. ${ }^{8,9,10}$ Knowledge also holds an important role in someone's behavioral development. Good knowledge and behavior about oral hygiene are vital to prevent dental and oral diseases, to increase immune system, to repair oral function for increased appetite, and for nutritional improvement. Thus, maintaining oral hygiene is one of the methods to maintain the condition of elderly body. ${ }^{4,11}$

The Research of Basic Health (Riskesdas) 2007 shows that every citizen in Indonesia have averagely five broken teeth. ${ }^{11}$ According to Riskesdas data in 2013, the number of oral and dental issues in Indonesia is reaching $25.9 \%$ with $5.9 \%$ prevalence of tooth loss in the age group of 55-64, and $17.6 \%$ in the age group $>65$ cause by caries and periodontal diseases. ${ }^{9}$ To sum up, the oral and dental issues in Indonesia is not improved. In fact, the number of caries cases are found increasing in the elders.

The above description then becomes the background of this research. The aim is to gain information regarding knowledge and behavior of elders and the impact on general health at Banda Aceh, Kuta Alam region. The research result is expected to be a reference for knowledge, behavior and condition of oral cavity in the elderly people, also as a reference for the next researches.

\section{MATERIALS AND METHOD}

This is a kind of analytic study with cross sectional approach. Research population include whole members of Integrated Service Post at Kuta Alam region, Banda Aceh. The subject of research was the elders who came to the service post by November 2017, by which 40 names of elders were collected. Research subjects were collected by purposive sampling according to inclusive criteria; $>45$ years old, agreed to be a subject of research, physically and mentally healthy, and did not have systemic illness.

The data used in this research were the primary data collected from questionnaire and examination to the elders at the service post. The research started with a briefing to research subjects about the procedures and informed consent, continued by the instructions to fill the questionnaire forms, and then dental and oral examination by using Decayed Missing Filled Teeth index (DMF-T) and Oral Hygiene Index Simplified (OHIS) from which the subjects were classified as good, mediocre and poor according to WHO standard. Some of the given questions were about the latest visit to the dentist, the reason to visit the dentist and the oral implications as seen in Table 9. The results of the questionnaire were then arranged in cross tabulation and analyzed by using Spearman test.

\section{RESULTS}

According to the normality test by using SaphiroWilk, data were found distributed normally with significance value of $p=0,538$ ( $p>0,05)$. Subjects of research consisted of 20 male elders (50\%) and 20 female elders $(50 \%)$. According to age classifycation, research subjects consisted of 23 elders of 46-55 years old (57.5\%), 13 elders of $>65$ years old (32.5\%), and 1 elder of 75-90 years old (2.5\%). The characteristics of subjects were 17 housewives (42.5\%), 5 retirees $(5 \%), 14$ entrepreneurs (35\%) and 4 civil servants $(10 \%)$.

Table 1.The frequency distribution to the reason for elders to visit the dentists

\begin{tabular}{llcc}
\hline \multirow{2}{*}{ No } & $\begin{array}{c}\text { Reasons to } \\
\text { Visit The }\end{array}$ & \multicolumn{2}{c}{ Total } \\
\cline { 3 - 4 } & Dentist & $\begin{array}{l}\text { Number } \\
\text { (people) }\end{array}$ & Percentage(\%) \\
\hline 1 & Regular Check & 5 & 12,5 \\
2 & Incidental & 35 & 87,5 \\
\multicolumn{2}{l}{ Total } & 40 & 100 \\
\hline
\end{tabular}

According to Table 1 and 2, the research subjects stated some reasons to visit the dentist and the time estimation of their recent visits. According to the statement from $25 \%$ of research subjects, their latest visits to the dentist were 2 to 10 years ago, even $5 \%$ stated their absence of dental check. 
Table 2.The frequency distribution to the late visits to the dentist

\begin{tabular}{lcll}
\hline \multirow{2}{*}{ No } & $\begin{array}{c}\text { Recent } \\
\text { Dental } \\
\text { Check }\end{array}$ & $\begin{array}{l}\text { Number } \\
\text { (people) }\end{array}$ & $\begin{array}{l}\text { Percentage } \\
(\%)\end{array}$ \\
\hline 1 & $\begin{array}{l}\text { P } 12 \\
\text { months }\end{array}$ & 21 & 52,5 \\
2 & $1-2$ years & 9 & 22,5 \\
3 & $2-5$ years & 2 & 5 \\
4 & $5-10$ years & 3 & 7,5 \\
5 & $>10$ years & 3 & 7,5 \\
6 & None & 2 & 5 \\
& Total & 40 & 100 \\
\hline
\end{tabular}

Table 3 shows the criteria of subjects according to the knowledge and behavior on the oral health, which is divided by category and gender.

Table 3.The frequency distribution of subjects' criteria according to knowledge and behavior of oral health

\begin{tabular}{lcccc}
\hline Knowledge & & \multicolumn{2}{c}{ Gender } & \\
\cline { 3 - 4 } $\begin{array}{l}\text { and } \\
\text { Behavior }\end{array}$ & Total & Male & Female & $(\%)$ \\
\hline Good & 6 & 6 & 0 & 15 \\
Mediocre & 17 & 5 & 12 & 42,5 \\
Poor & 17 & 9 & 8 & 42,5 \\
Total & 40 & 20 & 20 & 100 \\
\hline
\end{tabular}

From the measurement by DMFT index, research category was found very high, with average value of 11,725 . Every subject has averagely 3 teeth with caries and 8 loss teeth caused by caries (Table 4).

Tabel 4. Distribusi nilai rata-rata DMFT

\begin{tabular}{ll}
\hline & $\mathbf{n}=\mathbf{4 0}$ \\
\hline Average DMF-T & 11,725 \\
Average D-T & 2,72 \\
Average M-T & 7,7 \\
Average F-T & 1,3
\end{tabular}

According to the correlation test by using Spearman test, it was found that there is a strong relation between knowledge and behavior towards oral health based on DMFT index, with correlation value $r=0,835$.

The results of OHIS examination shows there were 23 elders with poor oral hygiene $(57.5 \%)$, with 10 females and 13 males. (Table 5)
Table 5.The frequency distribution of research subjects according to OHIS scores

\begin{tabular}{|c|c|c|c|c|c|}
\hline $\mathbf{N}$ & \multirow[b]{2}{*}{ OHIS } & \multicolumn{2}{|c|}{ Gender } & \multirow[b]{2}{*}{ Total } & \multirow[b]{2}{*}{$\%$} \\
\hline $\mathbf{o}$ & & Male & Female & & \\
\hline 1 & Good & 2 & 1 & 3 & 7,5 \\
\hline 2 & Mediocre & 8 & 6 & 14 & 35 \\
\hline \multirow[t]{2}{*}{3} & Poor & 10 & 13 & 23 & 57,5 \\
\hline & Total & 20 & 20 & 40 & 100 \\
\hline
\end{tabular}

Table 6 shows the relation between OHIS scores and ages, and poor OHIS was mostly found at the age of 46-55.

Table 6. Cross tabulation between OHIS and ages

\begin{tabular}{|c|c|c|c|c|c|}
\hline \multirow[b]{2}{*}{ No } & \multirow[b]{2}{*}{ OHIS } & \multicolumn{3}{|c|}{ Age (Years Old) } & \multirow{2}{*}{ Total } \\
\hline & & $46-55$ & $56-65$ & $>65$ & \\
\hline 1 & Good & 2 & 1 & 0 & 3 \\
\hline 2 & Mediocre & 10 & 3 & 1 & 14 \\
\hline \multirow[t]{2}{*}{3} & Poor & 11 & 9 & 3 & 23 \\
\hline & Total & 23 & 13 & 4 & 40 \\
\hline
\end{tabular}

Looking between OHIS on the elders and the occupation on the 17 housewives, it was found that there were 12 people with poor OHIS score (Table 7).

Table 7. Cross tabulation between OHIS with occupation

\begin{tabular}{llllll}
\hline & \multicolumn{5}{c}{ Occupation } \\
\cline { 2 - 6 } OHIS & $\begin{array}{l}\text { House } \\
\text { wives }\end{array}$ & $\begin{array}{l}\text { Reti- } \\
\text { rees }\end{array}$ & $\begin{array}{l}\text { Entrepre- } \\
\text { neurs }\end{array}$ & $\begin{array}{l}\text { Civil } \\
\text { Ser- } \\
\text { vant }\end{array}$ & $\begin{array}{l}\text { To- } \\
\text { tal }\end{array}$ \\
\hline $\begin{array}{l}\text { Good } \\
\text { Medio- } \\
\text { cre }\end{array}$ & 0 & 1 & 1 & 1 & 3 \\
Poor & 12 & 4 & 6 & 2 & 14 \\
Total & 17 & 55 & 14 & 4 & 23 \\
\hline
\end{tabular}

Correlating Knowledge and Behavior of elders with OHIS examination, 2 people with good knowledge and behavior were found having good OHIS results. In contrast, elders with poor knowledge and behavior from total 17 people, were found having poor OHIS results. (Table 8) 
Table 8. Cross Tabulation of Knowledge and Behavior compared to OHIS

\begin{tabular}{lllll}
\hline $\begin{array}{c}\text { Knowledge } \\
\text { and } \\
\text { Behavior }\end{array}$ & Good & Mediocre & Poor & Total \\
\cline { 2 - 5 } Good & 2 & 4 & 0 & 6 \\
Mediocre & 1 & 10 & 6 & 17 \\
Poor & 0 & 0 & 17 & 17 \\
\hline Total & 3 & 14 & 23 & 40 \\
\hline
\end{tabular}

According to the correlation examination by using Spearman Test, strong relation was found between knowledge and behavior towards oral health and DMFT index $(r=0,835)$ an strong correlation with OHIS index $(r=0,828)$.

According to the obtained data from the questionnaire, it was found that the elders suffer from physiological implications in functions and activities due to changes in dental and oral conditions. (Ta-ble 9)

Table 9. The Frequency Distribution According to Criteria of Implications on The Elders Due to Oral Issue

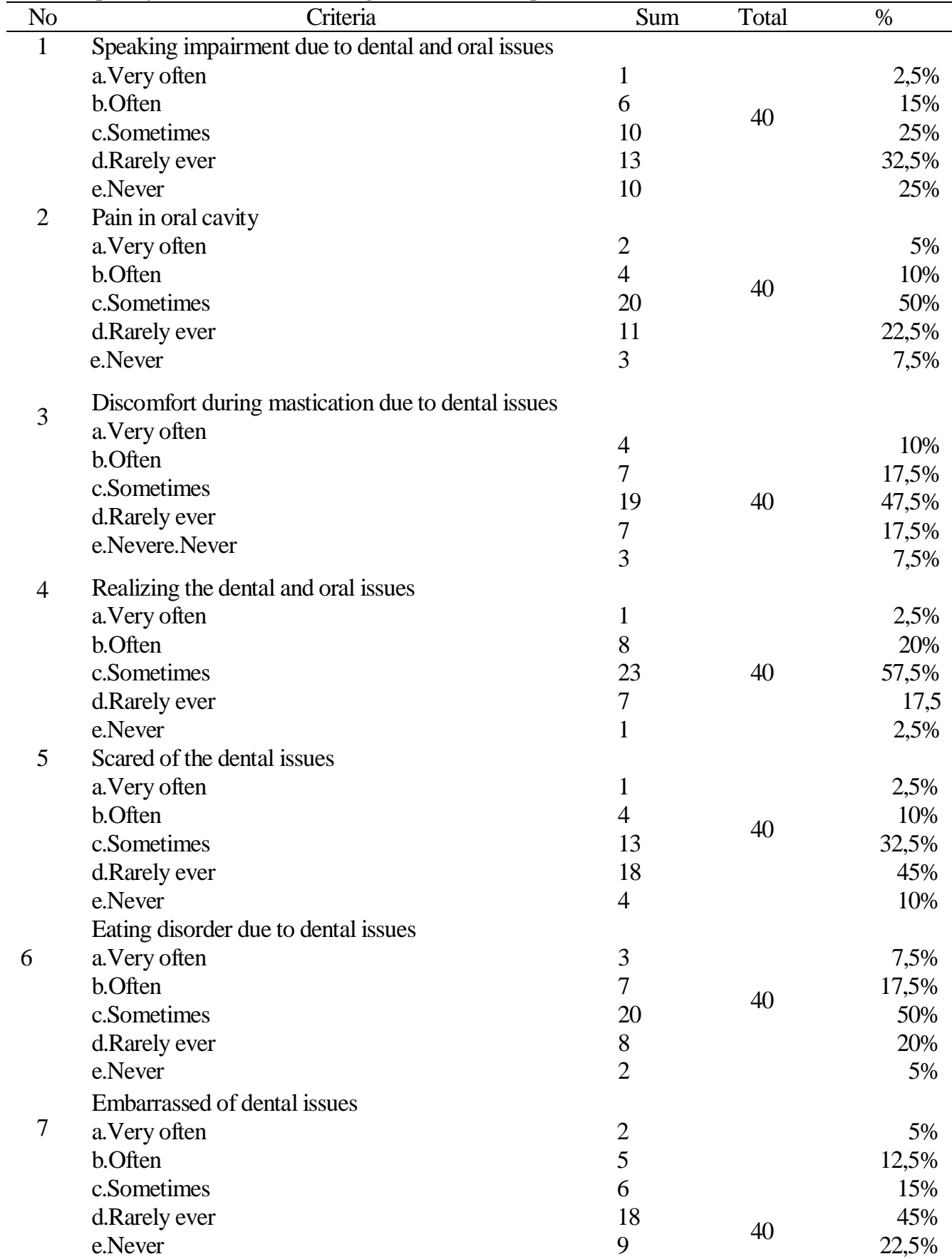




\begin{tabular}{|c|c|c|c|c|}
\hline \multirow{5}{*}{8} & $\begin{array}{l}\text { Difficulty in daily work due to dental issues } \\
\text { a.Very often }\end{array}$ & 1 & & $2,5 \%$ \\
\hline & b.Often & 2 & & $5 \%$ \\
\hline & c.Sometimes & 10 & 40 & $25 \%$ \\
\hline & d.Rarely ever & 16 & & $40 \%$ \\
\hline & e.Never & 11 & & $27,5 \%$ \\
\hline \multirow[t]{6}{*}{9} & Unable to do work properly due to dental issues & & & \\
\hline & b.Often & 1 & & $2,5 \%$ \\
\hline & c.Sometimes & 4 & 40 & $10 \%$ \\
\hline & dRarelv ever & 6 & & $15 \%$ \\
\hline & lover & 18 & & $45 \%$ \\
\hline & & 11 & & $27,5 \%$ \\
\hline
\end{tabular}

\section{DISCUSSION}

According to the results of the research, it was found that the biggest reason for the elders to visit the dentist is because they are having oral, making it to 35 people $(87.5 \%)$, while another 5 people $(12.5 \%)$ visit the dentist for regular check. In line with the research of Shah and friends ${ }^{12}$, it is stated that patients come to see the dentist only when they have unbearable pain.

Average of the research subjects had their teeth examined in $<12$ months ago, reaching 21 people $(52.5 \%)$ in total. There were 9 people $(22.5 \%)$ who came for dental examination the latest 1-2 years ago, 8 people (20\%) who visited 2 to $>10$ years ago, and there were 2 people (5\%) who never had dental examination.

According to the information from subjects, there were 23 people $(57.5 \%)$ who realized the dental and oral issues occurred to them. This indicated the lack of awareness from the elders regarding the importance of regular dental check, for which they neglect dental and oral health, in assumption that dental and oral health. ${ }^{13}$

In line with knowledge and behavior to the dental and oral health, there were 6 elders $(15 \%)$ who were considered good, 17 elders $(42.5 \%)$ were mediocre, and 17 elders $(42.5 \%)$ were poor. This is in accordance with the research of Nidyawati ${ }^{2}$ who stated that the knowledge of dental and oral health for the elders is still low. Another research also indicated the correlation between knowledge and behavior to dental and oral health. ${ }^{14}$ When education level is higher, the attention to dental and oral health will also be higher. In contrast, less education will cause low awareness to oral health. ${ }^{13}$

The analysis on questionnaire results shows that the elders experience some physiological disturbance in functional and activities due to some oral issues, with total 17 people (42.5\%) and 12 people
(30\%) had taste disorder due to dental and oral issues. There were 20 people $(50 \%)$ found complaining of the oral pain, 19 people $(47.5 \%)$ experienced discomfort while chewing, and 20 people (50\%) feel the eating inconvenience due to their dental problems. This is in accordance to Senjaya ${ }^{15}$ research who stated that the partial or whole teeth loss will give functional effect including speaking disorders and tooth loss will decrease the saliva production with the entire enzyme, causing the decreasing ability to taste and slowly affecting the ability to chew.

The incomplete set of teeth will cause inconvenience in eating and limitation to food consumption. 16 elders $(40 \%)$ found difficulties in daily work due to dental issues ad 14 elders (33\%) felt dissatisfaction to their life due to dental issues. Even there were 18 elders (45\%) who were not able to do activities well due to problems in their teeth. In line with Senjaya's research which stated that the partial or whole loss of teeth will cause emotional issues, specifically the confidence which then disrupt the daily activities. ${ }^{15}$

In this study, 11.725 DMFT were found on 1 elder with averagely 3 teeth with caries, 8 loss teeth 1 tooth filling. On the other hand, the result of OHIS examination index shows that good oral hygiene was found in 3 elders (7.5\%), mediocre category in 14 elders (14\%) and poor category in 23 elders $(57.5 \%)$.

This research also shows the relation between knowledge and behavior with each characteristic of subjects. According to age characteristics, there were 6 elders with good knowledge and behavior, consisting 2 elders of 46-55 years old, 3 elders of 56-65 years old, and 1 elder of more than 65 years old. For mediocre knowledge and behavior, there were 17 elders, consisting 13 elders of $46-55$ years 
old, 4 elders of 56-65 years old. For poor category of knowledge and behavior, there were 17 people consisting 8 elders of 46-55 years old, 6 elders of 56-65 years old and 3 elders of 65 years above. Based on the data, it can be summed that elders with average of 46-55 years old possess poor knowledge and behavior towards dental and oral health. Based on the Basic Health Research (Riskesdas) in 2013, there were $5.9 \%$ elders of 55-64 years old and $17.6 \%$ elders of $>65$ years old who experienced prevalence of tooth loss caused by caries periodontal diseases. ${ }^{16}$

The results of this research have also showed the correlation between OHIS and each characteristic of subjects. According to the relation between OHIS and the ages, it was found that average subjects possess poor OHIS. This study has showed 2 elders with good OHIS and 4 elders with mediocre OHIS. There were 17 elders with mediocre knowledge and behavior, with 1 possessing good OHIS, 10 mediocre, and 6 with poor OHIS. The elders with poor knowledge and behavior consist of 17 people with poor OHIS. This is in accordance to Purwoko's research in which stated that the knowledge on oral health has significant correlation with oral health status as seen from OHIS scores. ${ }^{17}$

Based on this study, the correlation between remaining teeth and the ages can be obviously seen. It was found in the group of elders of 46-55 years and old, there were 22 people with 10 remaining teeth. While in elderly group of 56-65 years old, there were 13 people with more than 10 remaining teeth. While in the age group of 65 years above, there was only 1 person with less than 10 remaining teeth and 3 people with more than 10 remaining teeth. On the other hand, the correlation between remaining teeth and genders can also be seen. It was found that there were 20 male elders consisting of 2 with less than 10 remaining teeth and 18 with more than 10 . While in female elders, there were 20 people with more than 10 teeth.

This study also shows us the correlation between the amount of teeth and the occupations. There were 17 housewives with more than 10 teeth.

From the research, the remaining teeth are also correlated with the obtained OHIS. It was found that 2 elders in the group with less than 10 teeth possessed poor OHIS. While elders with more than 10 teeth consisted of 18 people, where 3 of them possessed good OHIS, 14 mediocre and 21 poor.

The research results shows strong correlation between knowledge and behavior toward dental and oral health with DMFT index and OHIS, with correlation value for each at $r=0,835$ and $r=0,828$.
Other than that, this research also shows strong correlation between OHIS and DMFT with correlation value $r=0,931$. This is in accordance with the research of Rahardjo ${ }^{18}$ which stated that the better the knowledge and behavior towards dental and oral health, the better the oral health status and periodontal. This fact is also in line with the study of Sari DS and friends ${ }^{19}$ in 2015 which stated that elders with poor knowledge would also possessed poor oral health status.

This study shows the strong correlation between the knowledge and behavior towards dental and oral health with the amount of tooth loss, with correlation value $r=0,743$. In line with the research of Widayagdo $^{11}$ who stated that most elders show poor behavior toward oral hygiene. In this study, there were 16 elders who lost 6 to 28 teeth, while 24 others did not lose teeth or lose $>6$ teeth. Tooth loss is a risk factor from the mastication disorder. Some researches show the remaining teeth is a vital indicator to the efficiency of mastication ability. This factor will give impact to the desire to masticate and to swallow. The absence of antagonistic teeth will cause the over eruption and occlusive instability. ${ }^{20,21}$

This study also shows that the oral condition on will cause speaking, masticating and swallowing disorders. A study done by Misch involving 104 edentulous patients, $88 \%$ experienced speaking difficulty. ${ }^{22}$ In line with the study from David and friends ${ }^{23}$, there were $45 \%$ subjects in London who did not accept the tooth loss condition and experienced disruption in daily activities, lose confidence and did not accept the changes of their facial shapes.

According to the study from Wibisono and Ghozali, the poor oral condition, such as the massive tooth loss due to damage or untreated caries, will disrupt the oral functions and activities, which eventually will affect the nutrient status and quality of life, at the same time the food preparation before absorption, aside from its psychological and social aspects. ${ }^{24}$ The dental and oral condition will impact the metabolism and nutrient status, especially to the elders.

The selection of food will be disrupted due to the decreasing of masticating capacity. It can be summed that the oral health status holds a great role in the well-being and quality of life for the elders. Study on clean and healthy behavior in household arrangements in Depok by Munifah Abdat shows the still low participation of the community in health efforts. ${ }^{25}$ The poor health status will increase the risk of infection, chronic illness and mortality. ${ }^{26}$ 
The sample of this research is still limited in simple method, however it produces interesting results. Therefore it is expected that the results are used for materials to examine the oral conditions of the elders, also as a reference for the next researches.

Based on the survey results and the examination on the elders about knowledge and behavior towards dental and oral health, it can be concluded that the education level holds important correlation with the oral condition. From the survey, it was found that the elders still possess poor knowledge

\section{REFERENCES}

1. Badan Pusat Statistik. Statistik penduduk lanjut usia 2014. Jakarta: BPS RI, 2015: 20-3.

2. Nidyawati, N. Wicaksono, DA. Soewantoro, JS. Gambaran singkat pengetahuan dan kebersihan mulut pada masyarakat lanjut usia di kelurahan Rurukan kecamatan Tomohon Timur. JBM 2013; 5(1): 169-74.

3. Sutikno E. Hubungan antara fungsi keluarga dan kualitas hidup lansia. Med J Indonesia 2011; 2:73-9.

4. Tjahja I, Sintawati, Yovita TA. Gambaran karies gigi permanen di beberapa puskesmas kota dan kabupaten Bandung, Suka bumi serta Bogor tahun 2002. Media Litbang Kesehatan 2006; 16(4): 26-31.

5. Wijayanti. Hubungan kondisi fisik RTT lansiaterhadap kondisi sosial lansia di RW 03 RT 05kelurahan Tegalsari kecamatan Candisari. Jurnal Ilmiah Perancangan Kota dan Pemukiman. ENCLOSURE 2008; 7(1): 38-49.

6. Musacchio E, Perissinotto E, Binotto P, Sartori L, Silva-Netto F, Zambon S, et al. Tooth loss in the elderly and its association with nutritional status, socio-economic and lifestyle factors. Acta Odontol Scand. 2007; 65(2): 78-86.

7. Weijenberg RAF, Scherder EJA, Lobbezoo F. Mastication for the mind: the relationship between mastication and cognition in ageing and dementia. J Neu Bio Rev 2011; 35: 483-97.

8. Ramadhan A, Cholil, Sukmana BI. Hubungan tingkat pengetahuan gigi dan mulut terhadap angka karies di SMPN 1 Marabahan. Dentino Jurnal Kedokteran Gigi. 2016; 1(2): 173-6.

9. Ratmini NK, Arifin. Hubungan kesehatan mulut dengan kualitas hidup lansia. Jurnal Ilmu Gizi 2011; 2(2):139-47.

10. Africa CWJ, Reddy J. The Association between gender and tooth loss in a small rural population of South Africa. Sci J Cli Med 2013; 2(1):8-13.

11. Widayagdo A, Nugroho C. Kondisi rongga mulut pada lansia kabupaten Brebes. IOHJ 2017; 2(1): 9-16. about oral health, and elders of age 46-55 are those with the minimum knowledge level. On the other hand, this level of knowledge also has strong correlation with the poor DMFT and OHIS results. Survey also shows that the elders make a visit to the dentist only when they are having dental issues. Also from the questionnaire, the average elders' experienced inconvenience while chewing food, even show disability in properly doing the daily work due to embarrassment, emotional sensitivity and inconvenience caused by the dental issues.

12. Shah RJ, Diwan FJ, Diwan MJ, Chauhan VJ, Agrawal HS, Patel GC. A Study of the emotional effects of tooth loss in an edentulous Gujarati population and its association with depression. $\mathbf{J}$ Indian Prosthodont Soc 2015; 15(3): 237-43.

13. Davis DM, Fiske J, Scott B, Radford DR. The emotional effects of tooth loss: a preliminary quantitative study. BR Dent J 2000; 188(9): 5036.

14. Ikebe K, Matsuda K, Kagawa R, Enoki K, Yoshida M, Maeda Y, et al. Association of masticatory performance with age, gender, number of teeth, occlusal force and salivary flow in Japanese older adults: is aging a risk factor for masticatory dysfunction. Arch Oral Biol 2011; 56(10): 991-6

15. Senjaya AA. Gigi lansia. J Skala Husada. 2016; 13(1): 72-81.

16. Kementrian Kesehatan RI. Riset kesehatan dasar (Riskesdas 2013). Jakarta: Kemenkes RI, 2013: 112.

17. Purwoko. Hubungan pengetahuan dan sikap dengan status kesehatan gigi pada anak usia sekolah dasar di wilayah kerja puskesmas sawit I. Tesis. Surakarta: Universitas Sebelas Maret; 2011.

18. Rahardjo, Tri B. W. Kebijakan tentang kesejahteraan penduduk lansia di Indonesia serta kaitannya dengan upaya pembinaan kesehatan, termasuk bidang kesehatan gigi. Majalah Ilmiah Kedokteran Gigi 1996; 1(Edisi Khusus Foril V): 6878.

19. Sari DS, Arina YMD, Ermawati T. Hubungan pengetahuan kesehatan gigi mulut dengan status kebersihan rongga mulut pada lansia. IKESMA. 2015; 11(1):44-51.

20. Emami E, Souza RFd, Kabawat M, Feine JS. The impact of edentulism on oral and general health. In J Dent 2013; 2013: 1-7

21. Quaker AS. Consequences of tooth loss on oral function and need for replacement of missing teeth among patients attending Muhimbili dental 
clinic. Dissertation. Tanzaia: Muhimbili University of Health and Allied Sciences, 2011: 1-4.

22. Misch CE. Dental implant prosthetics $2^{\text {nd }}$ ed. St. Louis: Elsevier Mosby, 2015: 18.

23. Davis DM, Fiske J, Scott B, Radford DR. The emotional effects of tooth loss: a preliminary quantitative Study. BR Dent J 2000; 188(9): 503-6.

24. Wibisono A, Ghozali TD. Kebutuhan gigi palsu pada usia lanjut. Dalam: Martono H, Pranaka K, editor. Buku ajar Boedhi-Darmojogeriatri (ilmu kesehatan lansia) Ed.4. Jakarta: Balai Penerbit FKUI; 2010

25. Abdat M. Studi kualitatif tentang pelaksanaan program perilaku hidup bersih dan sehat (PHBS) tatanan rumah tangga.. Cakradonya Dent J.2017; 9(1): 62-72.

26. Junior HLR, Scelza MFZ, Boaventura GT, Custodio SM, Moreira EAM, Oliveira DdL. Relation between oral health and nutritional condition in the elderly. J Appl Oral Sci. 2012; 20(1): 38-44 